\title{
Juan Roberto Diago
}

IDALMA FONTIRROCHE

Nace el 23 de febrero de 1971 en Ciudad de la Habana, Cuba. Es graduado de la Academia de Artes Plásticas «San Alejandro», en 1990, miembro de la Unión Nacional de Escritores y Artistas de Cuba (UNEAC) y Profesor Consultante del Instituto Superior de Arte.

En su quehacer es portador de una profunda preocupación sobre los problemas sociales del hombre contemporáneo y la marginalidad racial, intelectual y cultural, centrando su atención en los últimos tiempos no sólo en la reflexión sobre estos temas sino en su presencia como gestor de importantes proyectos de participación sociocultural.

En su obra están presentes la simbología religiosa, el hombre, la tierra y la ciudad.

Sin perder el apego a su aguda crítica utiliza en sus composiciones el simbolismo dado por el color y el contraste. En la textura de su entramado abstracto, trabajada en diferentes tonos y materiales, y sobre los que pueden apa- recer o no, imágenes, contrastan la delicadeza y la fuerza. Dibujos, textos, collages y planos de colores apoyan la expresividad del artista.

Su obra aparece en las Colecciones del Museo Nacional de Bellas Artes, La Habana, Cuba; Galería Guislain Etats d'Art, París, Francia; Galería Cernuda Arte, Florida, EEUU; Pan American Art Gallery, Texas, EEUU; Galería Sacramento, Aveiro, Portugal; Coral Capital Art Collection, Ciudad Panamá, Panamá; Galería Spativm, Caracas, Venezuela; Fundación Kikoïne, París, Francia; Fundación Brownstone, París, Francia; Fundacion KAMÉLÉONE, Francia; District 798, Xin Dong Cheng Space for Contemporary Art, Beijing, China; Museo Fort Lauderdale, Florida, EEUU; CIFO Collection, Florida, EEUU; Stephen Cohen Gallery, New York, EEUU; Museo 54, New York, EEUU; Pizzutti Collection, Ohio, EEUU; Rubin Museum of Art: The Collection; Sammlung HGN/HGN Collection, Duderstadt, Germany.

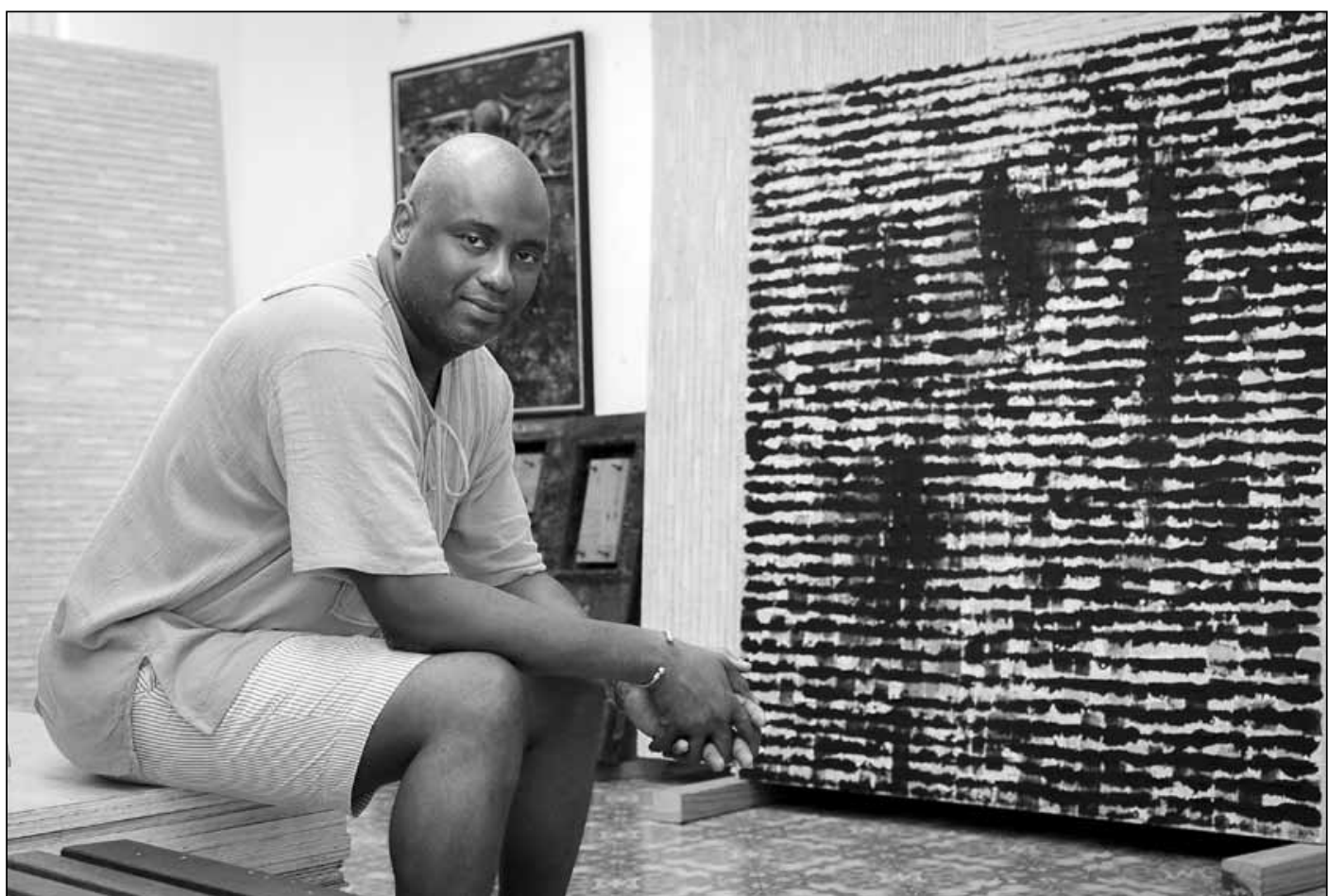

Roberto Diago. Fotografía de Alain Gutiérrez. 